\title{
PYRITE-BEARING SANDSTONE BLOCKS, WESTERN FINLAND
}

\author{
ANssi LonKA, \\ Geological Survey of Finland, Otaniemi, Finland \\ and \\ Heikni Papunen, \\ Institute of geology, University of Turku, Finland
}

\section{ABSTRACT}

Sandstone blocks with pyrite cement in the western coastal area of Finland have both concretionary and irregular external forms. In addition to them, a pyrite vein in a sandstone block and also a pyrite-cemented conglomerate with glauconite and phosphorite fragments have been described. Comparisons with some other pyrite concretions have been made and ten new chemical analyses are presented. The source of the blocks is evidently a (Middle-) Cambrian sandstone bed at the bottom of the Bothnian Sea.

\section{Introduction}

Marcasite and pyrite are the most abundant of the 30 species of authigenic sulfides occurring in sedimentary rocks (Degens 1965). According to Pettijohn (1957), sulfides are especially plentiful in rocks which are rich in organic matter and less common, though by no means rare, in many limestones and even sandstones. Marcasite is formed under acid conditions such as those in fresh water environments, whereas pyrite occurs in marine sediments deposited under neutral or alkaline conditions.

Unmetamorphic or weakly metamorphosed sedimentary rocks are rare in Finland; only the Jotnian (Precambrian) sandstones of Satakunta, the Muhos formation and the Cambrian sediments of Ahvenanmaa ( $\AA$ land) have been investigated. However, no sulfide-bearing horizons or their parts have been found in them. In Fenno- scandia as a whole, sulfide-bearing sedimentary rocks are well known, e.g. the Eocambrian sandstones of Laisvall, Sweden (Grip, 1954), some sulfide-bearing Cambrian sandstones of South Norway (Antun, 1967) and sulfide-rich Cambrian alum shales (in Swedish Alunaskiffer). The latter, however, are not sandstones.

Thus it seems significant, that dozens of pyrite-bearing sandstone blocks have been found over the years in western and southwestern Finland, mainly on the coastal area of the Bothnian Sea. They have previously been studied by Marmo (1952), Marmo and Laitakari (1952) and Kulonpalo (1957). During the exploration carried out by the Suomen Malmi Co from to 1965 some new pyrite-bearing sandstone blocks were found on the coastal area between the towns of Vaasa and Pori (Fig. 1). Some were found by »spare-time explorers» and others by geologists of the company. The characteristic features of 
these blocks throw new light on the origins of the pyrite-bearing sandstone blocks of western Finland. In this study, comparisons with some other concretionary pyrite-blocks are also made.

\section{Occurrence and block types}

The bedrock map of the Bothnian Sea, simplified from the map of Veltheim (1962), is presented in Fig. 1. The sites of the blocks described by Marmo and Laitakari (1952) and by Kulonpalo (1957) have been drawn on the map as have also the blocks of Siipyy (Sample 1), Pomarkku (2), Enskär (3) and Skaftung (4) described in this study.

On the basis of their external shapes the sulfide bearing sandstone blocks can be divided into two groups: 1) roundish, concretionary blocks and 2) irregular blocks (erratics). The bulk of the blocks described by Marmo and Laitakari (1952) belong to the former group as do also those of Enskär and Pomarkku to be described here, whereas the blocks of Siipyy and Skaftung belong to the latter group.

The internal textures can also be taken as a basis of classification. Marmo and Laitakari (1952) divided their samples into sandstone-like concretions in which the pyrite and rarely the marcasite occur as the cement of the sandstone, into compact sulfide concretions and into concretions containing marcasite and slaty matter. The samples from the Pori-Vaasa area in this study belong to the group of the sandstonelike concretions with the exception of the block of Skaftung, in which the suifide matter occurs as a vein. By way of comparison the compact spherulitic pyrite segregations from Gotland and southern Sweden were also studied.

The sandstone blocks are divided into the following groups:

1) sandstone with pyrite and occasionally carbonate cement

2) sandstone with a pyrite vein

3) conglomerate with pyrite cement.

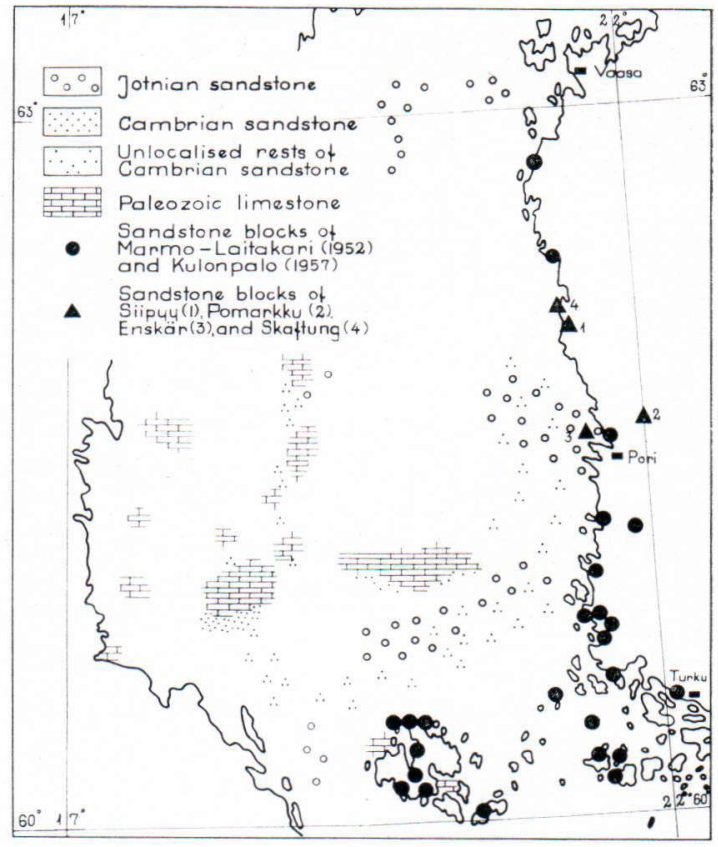

Fig. 1. Map of the Prequaternary rocks in the area of the Bothnian Sea (simplified from the map of Veltheim 1962) showing the localities of the sandstone blocks.

Sandstone, with pyrite cem e n t: Quartz is the main sedimentary minrale. In addition a little plagioclase and rarely tourmaline occur. It is difficult to measure the roundness of the sand grains because pyrite has slightly replaced the margins of the sand grains (Fig. 2). Generally the pyrite totally fills the interstices of sand grains, but in some places also silica cement or cavities without cement (Fig. 3) can be seen. The amount of sulfides varies slightly.

The blocks from Enskär which were found on the rocky shore of the isle of Pikku Enskär belong to this group. They have concretionary external forms with knobby roundish surfaces. Fig. 3 presents the microtexture of the sandstone with pyrite cement.

The external forms of the block from Siipyy are irregular. It is about $50 \times 70 \times 100 \mathrm{~cm}$ in size. One half of this angular sandstone erratic has carbonate cement whereas the other half is cemented by pyrite. The pyrite from the pyrite- 


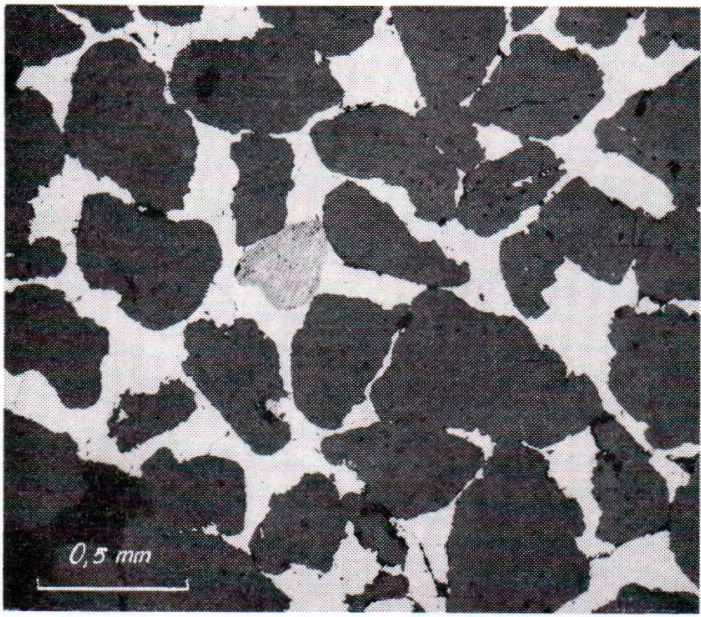

Fig. 2. Sandstone cemented by pyrite. Pyrite white, quartz almost black. Note the rectilinear boundaries between pyrite and quartz, which are caused by the idiomorphic crystal faces of the pyrite. Polished section. Block from Siipyy.

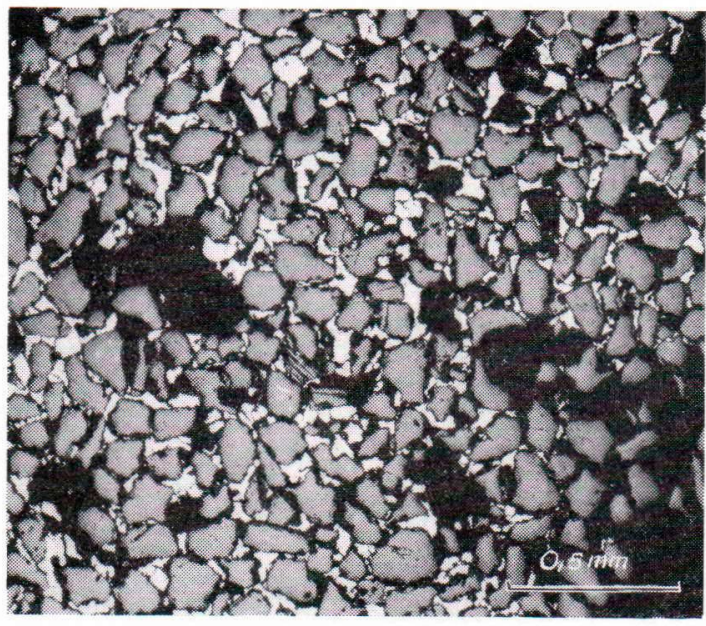

Fig. 3. Sandstone with a sparse pyrite cement. Pyrite is white, quartz grains are gray and holes are black. Polished section. Blocks from Enskär.

bearing part penetrates into the carbonate-bearing half of the block and the intermediate zone is breccia-like. As the block has no concretionary forms or textures, there is no reason to call it a pyrite-concretion. It seems to be a part of a sandstone layer with pyrite cement. Fig. 2 presents the microtexture of the block.

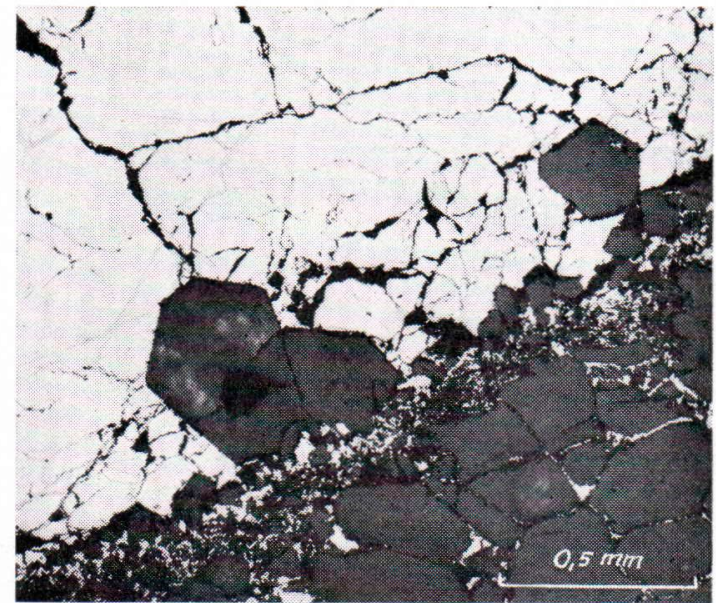

Fig. 4. Idiomorphic quartz crystals (gray) in a pyrite (white) vein. Note also the scattered pyrite cement between the sand grains in the lower right hand part of the picture and the fine-grained wall-zone of the pyrite vein. Polished section, sample from Skaftung, Siipyy.

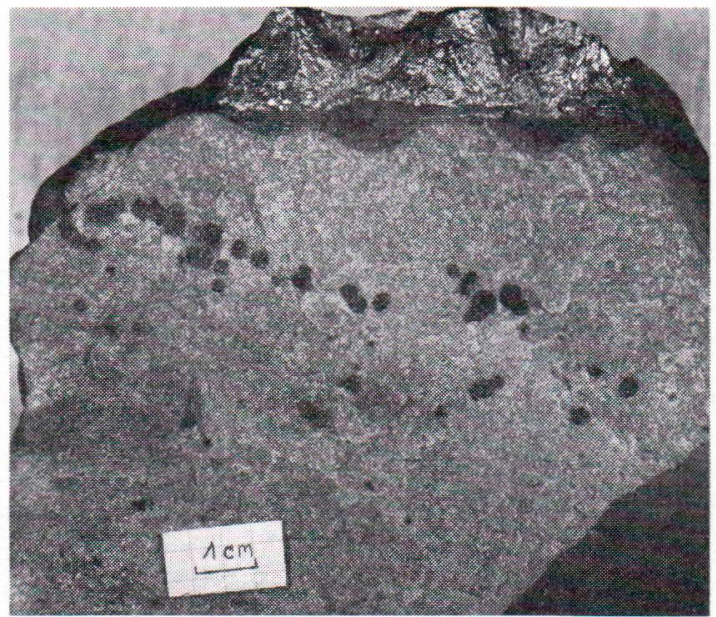

Fig. 5. Pyrite vein in sandstone block (uppermost part of the picture). Below the compact pyrite a zone of pyritecemented sandstone occurs (gray). In the sandstone there are roundish pyrite-cemented parts of rocks. Skaftung, Siipyy.

Sandstone with a pyrite vein: Reddish sandstone blocks occur abundantly on the sea-shore in the village of Skaftung in the commune of Siipyy. In one block a two centimetre broad pyrite vein was encountered. The sandstone is almost pure quartz with silica cement, but the amount of cementative matter is 
small. Large prismatic pyrite crystals have oriented perpendicularly to the walls of the vein. Near the walls the pyrite is fine-grained. Idiomorphic quartz crystals also occur in this finegrained wall zone (Fig. 4). This may prove that pyrite has formed as the filling of an open crack; on the other hand no marks of the intrusive character of the pyrite such as chilled contacts, brecciation etc. can be detected. In the immediate vicinity of the sulfide vein in the sandstone there is a rare pyrite cement. The breadth of the zone cemented by pyrite varies from $0.5 \mathrm{~cm}$ to $2 \mathrm{~cm}$. Also outside this zone, globules cemented by pyrite occur in the sandstone. The distance between the furthest globule and the vein is about $5 \mathrm{~cm}$ (Fig. 5).

Some block of conglomerate cemented by pyrite were found in Pomarkku. Dozens of pyrite-bearing sandstone blocks were met with in an open crack of the bedrock. All had concretionary, roundish forms ranging in size from one to about twenty centimetres. The bulk of them were the usual sandstone blocks with pyrite cement (type Enskär), but there were also some conglomerates among them.

Sand grains and especially rock fragments are well rounded in the conglomeratic sandstones. They vary in size from one to twenty millimetres. The cement is compact pyrite and totally fills the interstices of the grains. Sometimes it replaces quartz grains and also rock fragments. In addition to quartz and minor tourmaline and zircon grains, fragments of sandstone, conglomerate and shale occur. In some shale fragments there are many small framboidal pyrite spherules which evidently belong to the primary mineral association of the shale (Fig. 6) and are probably biogenic in origin (Papunen 1968). Also dense brownish fragments occur abundantly. According to qualitative chemical and $\mathrm{X}$-ray determinations they are phosphorite (Fig. 7). The cement of the conglomeratic fragments is chlorite or sometimes also phosphorite. The fragments are composed of subangular quartz grains and sand-

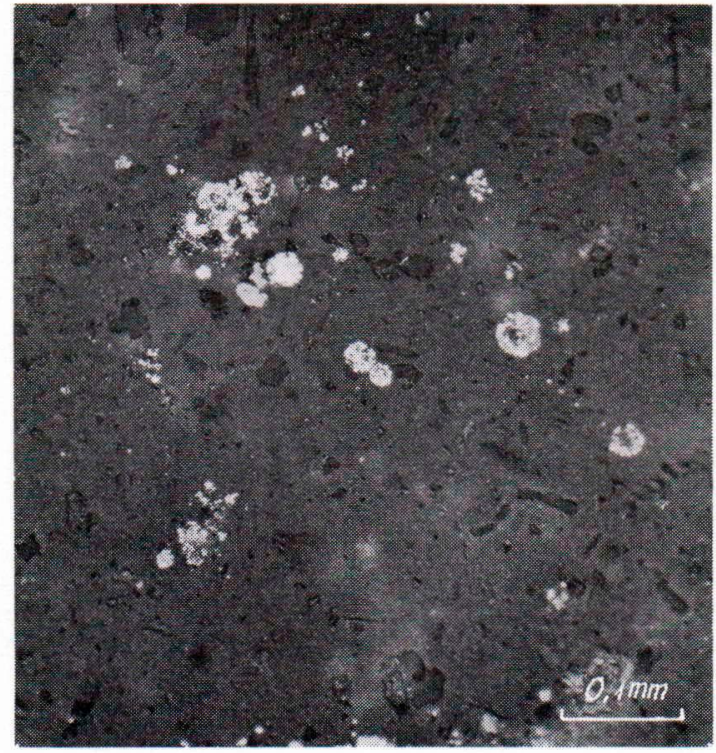

Fig. 6. Framboidal pyrite spherules (probably biogenic in origin) in a shale fragment of the conglomerate sample from Pomarkku. Pyrite white, shale gray, polished section.

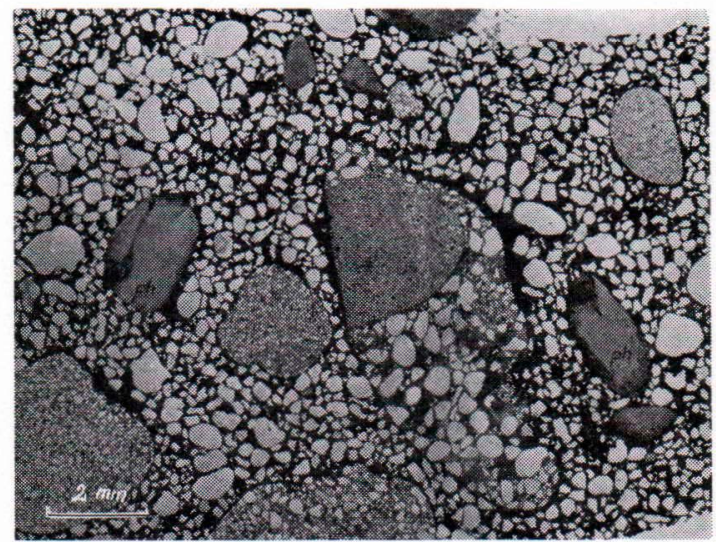

Fig. 7. Conglomerate with pyrite cement. Fragments are quartz, sandstone, phosphorite (ph) and conglomerate (middle part of the Fig.). Unpolarized transmitted light. Sample from Pomarkku.

stone fragments with chlorite cement (Figs. 7 and 8). Occasionally also small pyrite grains occur inside the fragments. Small green glauconite flakes have been met in the conglomerate as well as in the sandstone fragments.

The amount of pyrite varies and here and there sulfide-rich zones can be seen. In those 




Fig. 8. Well rounded conglomerate fragment containing angular quartz grains and shale in the conglomeratic sandstone of Pomarkku. Pyrite is white, quartz gray, polished section.

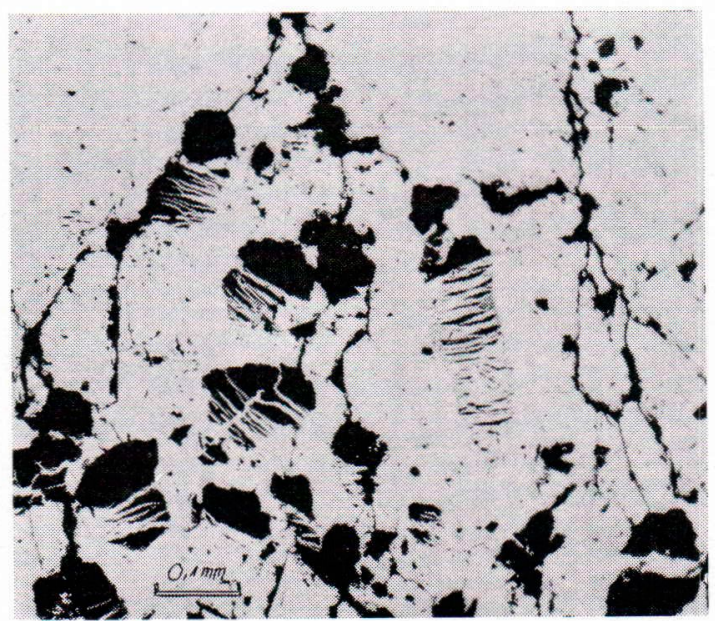

Fig. 9. Quartz grains are replaced and stretched by pyrite prisms which are almost vertical in the picture. Quartz is black, pyrite white. Polished section. Sample from Pomarkku.

cases, the pyrite is prismatic with the prisms perpendicular to the direction of the pyrite-rich zone. The replacement texture, as in Fig. 9, has developed perpendicularly to the prisms and it seems that the enclosed sand grains have elongated and cracked during the growth of the prismatic pyrite crystals.

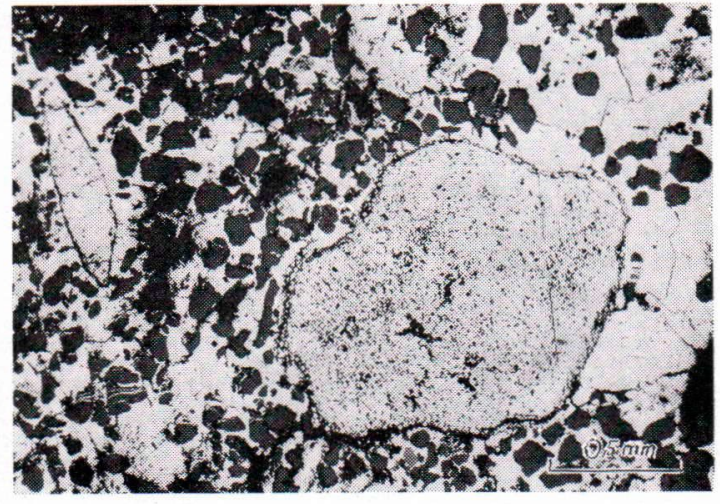

Fig. 10. Pyrite (white) accumulations, which may be pyritized fossils. Polished section, sample from Suhgrumägi, Tallinn.

By way of comparison a sulfide-bearing Cambrian sandstone of Suhgrumäki, Tallinn has been studied. It has a conglomerate texture identical with that of the Pomarkku blocks. The only sulfide mineral is pyrite. In addition to the textures described above, also peculiar pyrite fragments which may have fossiliferous forms (Fig. 10) occur in this conglomerate. Fragments of the same type, but not so well developed, have also been seen in the conglomerates of Pomarkku.

Compact pyrite concretions: In some cases a compact pyrite mass has been met with as the core of the sandstone concretions (Marmo and Laitakari, 1952 p. 9) as well as in many pyrite concretions of clay slates. The compact pyrite concretions with spherulitic textures generally occur in carbonate sediments. By way of comparison the roundish, compact concretions of Gotland (analysis no 6) and of the limestone quarry of Limhamn, Malmö, Sweden (anal. no 7) were investigated. The concretions of Gotland range from 5 to $25 \mathrm{~mm}$ in size and those of Limhamn from 5 to $15 \mathrm{~cm}$. They are usually spherical or ellipsoidal in shape. They have a fine-grained roundish core composed of equidimensional pyrite crystals and calcite. Prismatic pyrite crystals are arranged radially around the core. On the surfaces of the concretions small faces of pyrite crystals can be seen. 
TABLE 1.

Chemical analyses of some pyrite-bearing sandstone blocks.

\begin{tabular}{|c|c|c|c|c|c|c|c|c|c|c|c|}
\hline Sample & $\begin{array}{c}\mathrm{S} \\
\%\end{array}$ & $\begin{array}{l}\mathrm{Fe} \\
\%\end{array}$ & $\begin{array}{c}\mathrm{FeS}_{2} \\
\%\end{array}$ & $\begin{array}{c}\mathrm{Cu} \\
\mathrm{ppm}\end{array}$ & $\begin{array}{c}\mathrm{Ni} \\
\mathrm{ppm}\end{array}$ & $\begin{array}{c}\text { As } \\
\mathrm{ppm}\end{array}$ & $\begin{array}{l}\text { Co } \\
\%\end{array}$ & $\begin{array}{l}\mathrm{Ag} \\
\%\end{array}$ & $\begin{array}{l}\mathrm{Pb} \\
\%\end{array}$ & $\begin{array}{c}\mathrm{Mn}_{\%} \\
\%\end{array}$ & $\begin{array}{l}\mathrm{Ti} \\
\%\end{array}$ \\
\hline $1 \ldots \ldots \ldots \ldots$ & 50.5 & 42.8 & 93.3 & 10 & $\sim 0$ & $\sim 0$ & $<0.001$ & $<0.001$ & $<0.01$ & $<0.01$ & 0.010 \\
\hline$\ldots \ldots \ldots \ldots$ & 41.6 & 35.4 & 77.0 & 20 & 20 & 10 & 0.003 & $<0.001$ & $<0.01$ & $<0.01$ & 0.16 \\
\hline$\ldots \ldots \ldots$ & 42.6 & 35.5 & 78.1 & 30 & 10 & $\sim 0$ & $<0.001$ & $<0.001$ & $<0.01$ & $<0.01$ & 0.008 \\
\hline $4 \ldots$ & 14.5 & 13.0 & 27.5 & 25 & 25 & $\sim 0$ & & & & & \\
\hline $5 \ldots$ & 35.1 & 26.3 & 61.4 & 20 & 15 & 20 & 0.002 & $<0.001$ & $<0.01$ & $<0.01$ & 0.13 \\
\hline $6 \ldots$ & 49.6 & 41.9 & 91.5 & 15 & 10 & $\sim 0$ & 0.003 & $<0.001$ & $<0.01$ & $<0.01$ & 0.005 \\
\hline $7 \ldots$ & & & & & & & 0.001 & $<0.001$ & $<0.01$ & $<0.01$ & 0.005 \\
\hline $8 \ldots$ & 39.4 & 33.9 & 73.3 & 20 & 20 & 50 & & & & & \\
\hline $9 \ldots \ldots \ldots$ & 20.2 & 16.8 & 37.0 & 20 & 15 & 20 & & & & & \\
\hline $10 \ldots \ldots \ldots \ldots \ldots$ & 26.2 & 22.5 & 48.7 & 15 & 50 & 110 & & & & & \\
\hline $11 \ldots$ & 26.9 & 23.5 & 50.4 & 20 & 25 & 20 & & & & & \\
\hline $12 \ldots$ & 31.2 & 27.0 & 58.2 & 15 & 15 & 30 & & & & & \\
\hline
\end{tabular}

Samples:

1. Pyrite vein in a sandstone block, Siipyy.

2. Conglomeratic sandstone with pyrite cement, Pomarkku.

3. Sandstone with pyrite and carbonate cement, pyrite rich layer, Siipyy.

4. Sandstone with pyrite and carbonate cement, breccia, Siipyy.

5. Sandstone block with pyrite cement, Enskär.

6. Compact pyrite concretion, Gotland.

7. Compact pyrite concretion, Limhamn, Malmö, Sweden.

8. Cambrian sandstone conglomerate with pyrite cement, Suhgrumägi, Tallinn.

9. Concretionary sandstone block with pyrite cement, Kökar, SW-Finland.

10. Sandstone with pyrite and marcasite cement, Ahvenanmaa.

11. Concretionary sandstone with pyrite cement, SW Finland.

12. Concretionary sandstone block with pyrite cement, Luonnonmaa, Naantali, Finland.

Samples 8-12 were taken for comparision from the collection of the University of Turku.

Sulfur, iron, copper, nickel and arsenic were analyzed by the X-ray fluorescence method (R. Lappalainen) and verified by an atomic absorption spectrophotometer (Perkin-Elmer).

Cobalt, silver, lead, manganese and titan were determined by a spectroscopic analysis (A. Löfgren).

The pyrite is optically clearly anisotropic. In the samples from Limhamn pyritized fossils occur abundantly. The carbonate mineral around the concretion was verified by the X-ray powder method as calcite.

It is typical of concretions in carbonate sediments that they have a spherulitic texture, but also the pyrite segregations in the alum shale described by Antun (1966) show spherulitic forms. In the pyritized sandstone concretions described in this study no spherulitic forms were encountered.

\section{Chemical composition and mineralogy of sulfides}

Table 1 presents the results of the analyses for sulfur, iron and trace-elements in the samples. An X-ray fluorescence method was used to determine iron, sulfur, arsenic, copper and nickel (By Mr. R. Lappalainen). The results were confirmed with an atomic absorption spectrophotometer (Perkin - Elmer) by Mr. Papunen. For the analyses of the other trace-elements an optical spectroscope was employed (Mr. Arvo Löfgren).

Chalcophile cations and arsenic evidently occur in pyrite because no other sulfide mineral has been found in the samples. In particular large prismatic pyrite crystals are anisotropic in polished sections, which, according to Marmo and Laitakari (1952), is due to high arsenic content of the pyrite. A correlation between the composition and anisotropy of the pyrite was not noted by the present authors and the true 
cause of the anisotropy of the pyrite lies in the low symmetry of its crystal structure as proposed by Stanton (1957).

The cell edge of the anisotropic pyrites was measured by the Debye-Scherrer method and was found to be $5.418 \pm 0.002 \AA$ within limits of error. No marcasite was encountered in the samples of this study.

\section{Discussion}

The pyrite-cement of sandstones can be either syngenetic or epigenetic. A type example of the latter case is the sulfide deposit of Laisvall, where the sulfides originate from the inner parts of the Caledonian mountain chain. It is a typical hydrothermal replacement deposit and the paragenesis of the ore consists of galena, sphalerite, pyrite, barite, calcite, fluorite and sericite (Grip, 1954). Even at Laisvall the sulfides occur as cement of Eocambrian sandstone. According to the chemical analysis, the abundances of traceelements in the pyrite of the sandstones described here are very low. The compositions agree well with those of the sedimentary pyrite described by Degens (1965, p. 162) and thus the authigenic nature of the pyrite is evident.

According to previous investigations and to this study, most sandstone blocks with pyrite cement have concretionary, roundish external forms. But, in addition, also irregular erratics have been found which are evidently fragments of a sandstone bed with pyrite cement. The internal textures are similar in both concretionary blocks and erratics.

The pyrite of the sandstone blocks has often replaced the silica or carbonate cement of the sandstone, but also replacement of sand grains can be seen. The prismatic crystals in the pyrite vein in the sandstone block of Siipyy, and the prismatic pyrite with cracking-replacement textures of sand grains (Fig. 9) and especially the spherulitic concretions of carbonate sediments prove that a prismatic shape characterizes the concretionary pyrite, which has evidently crystallized at low temperatures. The growth of the prisms has been so vigorous that they have split and stretched the enclosed sand grains. The great form energy of pyrite is proved by the idiomorphic crystal faces of the cementative pyrite against the quartz grains in sandstone, which is illustrated e.g. in Fig. 2.

The large amount of pyrite-bearing sandstone blocks in the western and southwestern coastal area of Finland indicates that they originate from a sulfide-bearing sandstone horizon in the area of the Bothnian Sea. The large, layered block of Siipyy proves the occurrence of a real pyritecemented sandstone bed. Its stratigraphic position is not, however, self-evident.

According to the investigations of Marmo and Laitakari (1952, p. 13) »compared with the structure of specimens of Cambrian sandstone from Valkjärvi in Karelia and Esthonia, .... these concretions have their source in the CambroSilurian sediments at the bottom of Bothnian Gulf». The identity of the Cambrian conglomeratic sandstone from Suhgrumäki, Tallinn (Estonia) with the pyritiferous conglomeratic blocks of Pomarkku previously described is obvious. Also phosphorite fragments of conglomerates are well known in some Cambrian sandstones, e.g. Magnusson et.al. (1963, p. 287) state that phosphorites are typical of Ordivician shales. Also Middle Cambrian formations in Kinnekulle, Sweden, contain beds of phosphorite- and glauconite-bearing sandstones (Magnusson et al. 1963 p. 260). Thus the source of pyritiferous sandstone blocks could be either the Middle Cambrian or Ordivician stratum in the area of the Gulf of Bothnia.

Acknowledgements - The authors are indebted to Messrs Rolf Lappalainen of Lohjan Kalkkitehdas Oy and Arvo Löfgren of the Geological Survey of Finland for chemical analyses, to Professor Aarne Laitakari of the Geological Survey of Finland for the samples from Limhamn which he kindly put at the disposal of the authors, to Miss Lea Marjomaa for drawing the map and Mrs Gillian Häkli, B.A., for correcting the English. 


\section{REFERENCES}

Antun, Paul, (1967). Sedimentary pyrite and its metamorphism in the Oslo region. Norsk Geol. Tidskr. 47, pp. 211-235.

Degens, Egon, T. (1965). Geochemistry of Sediments, A Brief Survey. Prentice-Hall, Inc. New Jersey.

Grip, Erland, (1954). Blymalmen vid Laisvall, dess geologi och en jämförelse med några utländska förekomster. Geol. Fören. Stockholm Förh. Bd. 76, H. 3, pp. 357-380.

Kulonpalo, Max, (1957). Kiisukonkretioita. Geologi, IX. p. 28.

Magnusson, Nils, H., Lundqvist, G. \& Regnell, Gerhard, (1963). Sveriges geologi, fjärde upplagan, Kungl, boktr. Stockholm.

Marmo, Vladi, (1952). Rikkikiisukonkretioista. Geologi IV. p.
Marmo, Vladi and Laitakari, Aarne, (1952). Lounais-Suomen rikkikiisukonkretioista. Geotekn. julk. No 53 (English summary).

Papunen, Heikki, (1968). On the sulfides in the sediments of the Bothnian Sea. Bull. Géol. Soc. Finlande No 40.

Petтrjohn, F. J. (1957). Sedimentary Rocks, second edition, Harper \& Row, New York.

Stanton, R. L. (1957). Studies of polished surfaces of pyrite and some implications. Canadian Min. Vol. 6, p. 87.

Veltheim, Valto, (1962). On the Pre-Quaternary geology of the Bottom of the Bothnian Sea. Bull. Comm. geol. Finlande No 200.

Manuscript received, February 21, 1968. 